\title{
Alcohol Excites Cerebellar Golgi Cells by Inhibiting the $\mathrm{Na}^{+} / \mathrm{K}^{+}$ATPase
}

\author{
Paolo Botta', Fabio M Simões de Souza ${ }^{2}$, Thomas Sangrey ${ }^{2}$, Erik De Schutter ${ }^{2,3}$ \\ and C Fernando Valenzuela*,
}

'Department of Neurosciences, School of Medicine, University of New Mexico Health Sciences Center, Albuquerque, NM, USA; ${ }^{2}$ Computational Neuroscience Unit, Okinawa Institute of Science and Technology, Okinawa, Japan; ${ }^{3}$ Department of Theoretical Neurobiology, University of Antwerp, Wilrijk, Belgium

\begin{abstract}
Alcohol-induced alterations of cerebellar function cause motor coordination impairments that are responsible for millions of injuries and deaths worldwide. Cognitive deficits associated with alcoholism are also a consequence of cerebellar dysfunction. The mechanisms responsible for these effects of ethanol are poorly understood. Recent studies have identified neurons in the input layer of the cerebellar cortex as important ethanol targets. In this layer, granule cells ( $\mathrm{GrCs}$ ) receive the majority of sensory inputs to the cerebellum through the mossy fibers. Information flow at these neurons is gated by a specialized pacemaker interneuron known as the Golgi cell, which provides divergent GABAergic input to thousands of GrCs. In vivo electrophysiological experiments have previously shown that acute ethanol exposure abolishes GrC responsiveness to sensory inputs carried by mossy fibers. Slice electrophysiological studies suggest that ethanol causes this effect by potentiating GABAergic transmission at Golgi cell-to-GrC synapses through an increase in Golgi cell excitability. Using patch-clamp electrophysiological techniques in cerebellar slices and computer modeling, we show here that ethanol excites Golgi cells by inhibiting the $\mathrm{Na}^{+} / \mathrm{K}^{+}$ATPase. Voltage-clamp recordings of $\mathrm{Na}^{+} / \mathrm{K}^{+}$ATPase currents indicated that ethanol partially inhibits this pump and this effect could be mimicked by low concentrations of ouabain. Partial inhibition of $\mathrm{Na}^{+} / \mathrm{K}^{+} \mathrm{ATPase}$ function in a computer model of the Golgi cell reproduced these experimental findings. These results establish a novel mechanism of action of ethanol on neuronal excitability, which likely has a role in ethanol-induced cerebellar dysfunction and may also contribute to neuronal functional alterations in other brain regions.

Neuropsychopharmacology (2010) 35, 1984-1996; doi:I0.1038/npp.2010.76; published online 2 June 2010
\end{abstract}

Keywords: ethanol; cerebellum; electrophysiology; acute; firing; modeling

\section{INTRODUCTION}

The cerebellum controls motor coordination and also has a role in higher-order cognitive and emotional functions (Ito, 2006; Schmahmann, 2004; Tesche and Karhu, 2000). Cerebellar abnormalities contribute to the pathophysiology of several neuropsychiatric disorders including schizophrenia, depression, autism, and alcoholism (Cheron et al, 2008; Fitzpatrick et al, 2008; Gowen and Miall, 2007). Frontocerebellar circuitry alterations contribute to executive function abnormalities in alcoholics (Sullivan et al, 2003). Short- and long-term exposure to ethanol causes cerebellar dysfunction and this is responsible for a large number of accidental

*Correspondence: Dr CF Valenzuela, Department of Neurosciences, School of Medicine, University of New Mexico Health Sciences Center, MSC08 4740, BMSB I 45-9I 5 Camino de Salud, N.E, Albuquerque, NM 87|3|-000।, USA, Tel: + 505272 3128, Fax: + 505272 8082, E-mail: fvalenzuela@salud.unm.edu

Received I March 20I0; revised 20 April 20I0; accepted I May 2010 injuries and deaths worldwide. Fetal alcohol spectrum disorder is characterized by cerebellar neuronal loss and synaptic transmission/plasticity alterations (Servais et al, 2007). Despite the importance of the cerebellum as a target of ethanol, little is known about its mechanism of action in this brain region.

The innermost layer of the cerebellar cortex is the granule cell $(\mathrm{GrC})$ layer, which is the gateway of mossy fiber input from the corticopontine system, the brain stem, and the spinal cord to the cerebellar cortex. This layer contains the glutamatergic GrCs and the GABAergic Golgi cells (GoCs). GoCs provide strong GABAergic input to $\mathrm{GrCs}$, making them a high signal-to-noise filtering unit. GrCs receive tonic GABAergic input through high-affinity, extrasynaptic typeA $\gamma$-aminobutyric acid receptors $\left(\mathrm{GABA}_{\mathrm{A}} \mathrm{Rs}\right)$ that are activated both by spillover of GABA released from GoCs and ambient GABA levels (Rossi et al, 2003). In vivo electrophysiological studies showed that ethanol acutely inhibits GrC responses to mossy fiber input triggered by sensory stimulation (Huang and Huang, 1992, 2007). 
This effect of ethanol could be a consequence of increased tonic GABAergic currents in GrCs (Carta et al, 2004; Hanchar et al, 2005). Studies suggest that the ethanolinduced increase in tonic GABAergic currents is, in part, mediated by enhanced GABA spillover from GoCs (Botta et al, 2007a, b; Carta et al, 2004). The enhancement of GABA spillover is likely a consequence of an ethanol-induced increase of spontaneous action potential firing in GoCs (Carta et al, 2004; Freund et al, 1993). The mechanism by which ethanol excites GoCs is currently unknown.

GABAergic Golgi cells are essential for normal motor control, as shown by a study in which these neurons were selectively ablated in mice (Watanabe et al, 1998). GoC apical dendrites extend into the molecular layer, where they receive GABAergic input from molecular layer interneurons and glutamatergic input from parallel fibers (Dieudonne, 1998; Vos et al, 1999). GoC basal dendrites receive mossy fiber input (Ito, 2006; Kanichay and Silver, 2008; Vos et al, 1999). Climbing fibers may also provide excitatory input to GoCs (Xu and Edgley, 2008). GoCs are pacemaker neurons that tonically fire action potentials, and multiple intrinsic ionic mechanisms are thought to contribute to their autorhythmicity (Forti et al, 2006). Dopaminergic neurons in the ventral tegmental area also spontaneously fire action potentials and acute exposure to ethanol has been shown to excite these neurons independently of input from neighboring neurons (Brodie et al, 1999). On the basis of these findings with dopaminergic neurons, we hypothesized that ethanol increases $\mathrm{GoC}$ firing directly by modulating the intrinsic ionic mechanisms that control pacemaker activity of these neurons. We tested this hypothesis using slice electrophysiological techniques and computer modeling.

\section{MATERIALS AND METHODS}

For all the experiments, we used ethanol (95\%, spectrophotometric grade) from Sigma Chemical (St Louis, MO). D,L-APV, gabazine hydrobromide, CGP54626, and LY341495 were from Tocris-Cookson (Ellisville, MO). Tetrodotoxin (TTX) was from Calbiochem (San Diego, CA). $\mathrm{CdCl}_{2}$ was from Alfa Aesar (Ward Hill, MA). All other chemicals were from Sigma.

\section{Brain Slice Preparation}

All animal procedures were approved by the UNM-Health Sciences Center Institutional Animal Care and Use Committee and conformed to National Institutes of Health Guidelines. Experiments were performed in parasagittal vermis cerebellar slices that were prepared from 23 to $26-$ day-old male Sprague-Dawley rats (Harlan, Indianapolis, IN). Animals were killed by rapid decapitation under deep anesthesia with ketamine $(250 \mathrm{mg} / \mathrm{kg}$ i.p.) and $200-\mu \mathrm{m}$ thick slices were prepared with a vibratome (Leica Microsystems, Bannockburn, IL). Slices were cut in cold solution containing (in mM) 220 sucrose, $26 \mathrm{NaHCO}_{3}, 10$ glucose, $12 \mathrm{MgSO}_{4}$, $2 \mathrm{KCl}, 1.25 \mathrm{NaH}_{2} \mathrm{PO}_{4}, 0.2 \mathrm{CaCl}_{2}$, and 0.43 ketamine; this solution was pre-equilibrated with $95 \% \mathrm{O}_{2}$ plus $5 \% \mathrm{CO}_{2}$. Immediately after this procedure, slices were transferred to a chamber containing artificial cerebrospinal fluid (ACSF) and allowed to recover at $35-36^{\circ} \mathrm{C}$ for $35 \mathrm{~min}$, followed by storage at room temperature for up to $9 \mathrm{~h}$. The ACSF contained (in mM) $126 \mathrm{NaCl}, 2 \mathrm{KCl}, 1.25 \mathrm{NaH}_{2} \mathrm{PO}_{4}, 1$ $\mathrm{MgSO}_{4}, 26 \mathrm{NaHCO}_{3}, 2 \mathrm{CaCl}_{2}$, and 10 glucose equilibrated with $95 \% \mathrm{O}_{2}$ plus $5 \% \mathrm{CO}_{2}$. Recordings were carried out in a chamber perfused with ACSF at a rate of $2-3 \mathrm{ml} / \mathrm{min}$ and maintained at $32-33^{\circ} \mathrm{C}$.

\section{Loose-Patch Cell-Attached and Perforated-Patch Electrophysiological Recordings of GoC Firing}

Neurons were visualized using infrared-differential interference contrast microscopy and recordings performed with a Multiclamp 700B amplifier (Molecular Devices, Sunnyvale, CA). GoCs were primarily identified on the basis of their location in the GrC layer, larger size when compared with GrCs, and the presence of spontaneous action potential firing. In all cases, each slice was exposed once to a single ethanol concentration, and the duration of ethanol exposure was limited to $5 \mathrm{~min}$ to avoid the development of rapid tolerance.

The loose-patch cell-attached configuration (seal resistance $=8-30 \mathrm{M} \Omega$ ) was used to record action currents. The patch pipettes were filled with regular ACSF (tip resistance $=2-5 \mathrm{M} \Omega$ ) and the holding potential was $0 \mathrm{mV}$; it should be noted that the holding potential in loose-patch cell-attached experiments is unlikely to significantly affect the GoC resting membrane potential, because most of the current generated by the amplifier will leak across the loose seal rather than passing through the patch (Perkins, 2006). Action currents were detected by the presence of a downward and upward deflection in the current trace, as previously described (Forti et al, 2006; Kanichay and Silver, 2008). Recordings were discarded if the action current baseline frequency changed more than $20 \%$ or did not return to at least $50 \%$ of baseline during ethanol washout.

The effect of ethanol on $\mathrm{GoC}$ firing was further characterized using the perforated-patch configuration. An amphotericin-B stock solution was made fresh daily $(1 \mathrm{mg} /$ $\mathrm{ml}$ in dimethylsulfoxide). The stock solution was sonicated for $\sim 15 \mathrm{~min}$ and then continuously vortexed at a low speed for the duration of the recording session. The tips of the microelectrodes were prefilled with an internal solution containing (in $\mathrm{mM}$ ) $135 \mathrm{~K}$-gluconate, $5 \mathrm{KCl}, 10$ HEPES, 0.2 EGTA, 4.6 $\mathrm{MgCl}_{2}, 0.1 \mathrm{CaCl}_{2}, 4 \mathrm{Na}_{2}$-ATP, and 0.4 Na-GTP ( $\mathrm{pH} 7.35$ adjusted with $\mathrm{KOH}$ ) and then backfilled with the same internal solution containing $5 \mu \mathrm{g} / \mathrm{ml}$ of amphotericin$\mathrm{B}$; fresh amphothericin-B was mixed with an aliquot of internal solution every hour. Following formation of a 1-10 G $\Omega$ seal, the access resistance was used to monitor the progression of perforation, which was considered complete when it was between 40 and $80 \mathrm{M} \Omega$ (typically reached 10-40 min after G $\Omega$ seal formation). Recordings were performed in the current-clamp mode $\left(I_{\text {holding }}=0\right)$. Recordings were discarded if the membrane potential was less negative than $-55 \mathrm{mV}$, the action potential baseline frequency or membrane potential changed more than $20 \%$ from baseline, or any of these parameters did not return to at least $50 \%$ of baseline during ethanol washout. 


\section{$\mathrm{Na}^{+} / \mathrm{K}^{+}$ATPase Current Recordings}

The $\mathrm{Na}^{+} / \mathrm{K}^{+}$ATPase current was recorded as previously described (Hamada et al, 2003). Recordings were performed in the whole-cell patch-clamp configuration at a holding potential of $-25.1 \mathrm{mV}$ using ACSF containing the following neurotransmitter receptor blockers: kynurenic acid $(1 \mathrm{mM})$, D,L-APV $(50 \mu \mathrm{M})$, gabazine $(10 \mu \mathrm{M})$, strychnine $(1 \mu \mathrm{M})$, $10 \mu \mathrm{M}$ CGP $54626(10 \mu \mathrm{M})$, and LY $341495(1 \mu \mathrm{M})$. In addition, the ACSF was $\mathrm{Ca}^{2+}$-free and it contained $2 \mathrm{mM} \mathrm{BaCl}_{2}$, $1 \mathrm{mM} \mathrm{CsCl}, 0.2 \mathrm{mM} \mathrm{CdCl} 2,2 \mathrm{mM} \mathrm{NiCl} 2,20 \mu \mathrm{M}$ nifedipine, and $0.5 \mu \mathrm{M}$ TTX. The internal solution contained (in $\mathrm{mM}$ ) $100 \mathrm{NaOH}, 20$ tetramethylammonium hydroxide, 100 aspartic acid, 20 tetraethylammonium chloride, $2 \mathrm{MgCl}_{2}$, 5 EGTA, 5 Tris-ATP, 2.5 Tris $_{2}$-creatine phosphate, 5 glucose, and 10 HEPES ( $\mathrm{pH}$ adjusted to 7.2 with tetramethylammonium hydroxide). Under these conditions, membrane currents mediated by neurotransmitter receptors, voltage-gated $\mathrm{Ca}^{2+}$ channels, TTX-sensitive voltage-gated $\mathrm{Na}^{+}$channels, several $\mathrm{K}^{+}$channels subtypes, and the $\mathrm{Na}^{+} / \mathrm{Ca}^{2+}$ exchanger are minimized or abolished (Hamada et al, 2003).

\section{Electrophysiological Data Analyses}

Data were filtered at $2 \mathrm{kHz}$ and digitized at $5-50 \mathrm{kHz}$ with digidata1322A and pClamp-9 (Molecular Devices, Sunnyvale, CA) and analyzed with Clampfit-9 (Molecular Devices) and MiniAnalysis-6.0.3. (Synaptosoft, Decatur, GA). The coefficient of variation of the interspike interval $\left(\mathrm{CV}_{\text {ISI }}\right)$ was calculated as the ratio of the standard deviation to the mean interspike interval multiplied by 100 and was expressed as percent values. The action potential threshold value (spike threshold) was calculated with MiniAnalysis using the third differential function. The after-hyperpolarization (AHP) amplitude and time-to-peak were calculated with respect to the spike threshold value. Measurements of membrane potentials were corrected for liquid junction potentials. In all cases, effects of ethanol were calculated with respect to the average of control and washout responses. Data were statistically analyzed with Prizm 4 (GraphPad, San Diego, CA) and are presented as mean \pm SEM. The $\mathrm{Na}^{+} / \mathrm{K}^{+}$ ATPase currents were analyzed by fitting a Gaussian distribution to all-point histograms.

\section{Computer Modeling}

These studies were based on a previously published GoC model (Solinas et al, 2007). This model consists of five compartments including a soma $(32 \mathrm{pF})$, three dendrites (23 pF each), and an axon (90 pF). The soma has 12 voltagedependent ionic channels reproducing $\mathrm{GoC}$ intrinsic firing and responsiveness to somatic current injection. Currents used within the model were based on published experimental observations (D'Angelo et al, 2001; Dieudonne, 1998; Forti et al, 2006). We adopted a resting membrane potential of $-60 \mathrm{mV}$, and a passive leakage current with reversal potential at $-44.5 \mathrm{mV}$. All simulations were performed in the NEURON simulator-version 5.9 (Hines and Carnevale, 2001) using a time step of $25 \mu \mathrm{s}$. A Na ${ }^{+} / \mathrm{K}^{+}$ATPase was incorporated into the soma of the model; the equations that simulated the $\mathrm{Na}^{+} / \mathrm{K}^{+}$ATPase were described in Table S10 of Takeuchi et al (2006). The updated GoC model NEURON code with the $\mathrm{Na}^{+} / \mathrm{K}^{+}$ATPase component can be found at http://senselab.med.yale.edu/ModelDb/. The intracellular concentration of ATP was set at $5 \mathrm{mM}$. The ionic concentrations were set as follows: $\left[\mathrm{Na}^{+}\right]_{\mathrm{i}}=5 \mathrm{mM},\left[\mathrm{Na}^{+}\right]_{\mathrm{o}}=$ $145 \mathrm{mM},\left[\mathrm{K}^{+}\right]_{\mathrm{i}}=140 \mathrm{mM},\left[\mathrm{K}^{+}\right]_{\mathrm{o}}=5 \mathrm{mM},\left[\mathrm{Ca}^{2+}\right]_{\mathrm{i}}=50 \mathrm{nM}$, and $\left[\mathrm{Ca}^{2+}\right]_{\mathrm{o}}=2 \mathrm{mM}$, and synaptic inputs were absent. The density of the $\mathrm{Na}^{+} / \mathrm{K}^{+}$ATPase was calibrated to obtain an ethanol-induced $1 \mathrm{mV}$ change in resting membrane potential. Supplementary Figure 1A shows a simulation of the $\mathrm{Na}^{+} / \mathrm{K}^{+}$ATPase current density as a function of membrane potential in the GoC model; note that a current density of $\sim 1.75 \mathrm{pA} / \mathrm{pF}$ is predicted at a resting membrane potential of $-60 \mathrm{mV}$, in general agreement with current density values observed in dorsal root ganglion neurons (Hamada et al, 2003). The effect of TTX was modeled by turning off the voltage-gated $\mathrm{Na}^{+}$channel conductance. The effect of ouabain was simulated by systematically reducing the $\mathrm{Na}^{+} / \mathrm{K}^{+}$ ATPase component assuming a ouabain $\mathrm{IC}_{50}$ of $0.6 \mu \mathrm{M}$.

\section{RESULTS}

\section{Ethanol Increases the Firing Frequency and Regularity of Spontaneous Action Potential Firing}

Spontaneous GoC firing was initially assessed in the loosepatch cell-attached configuration using standard ACSF, where these neurons fired spontaneous action currents with a frequency $(f)$ of $4.6 \pm 0.9 \mathrm{~Hz}(n=11)$. Ethanol $(40 \mathrm{mM})$ reversibly increased firing $f$ by $1 \pm 0.3 \mathrm{~Hz}(p<0.05$ by onesample $t$-test $v s$ zero, $n=11$, Figure $1 \mathrm{a}$ and $\mathrm{b}$ ). In presence of ethanol, the $\mathrm{CV}_{\text {ISI }}$ was decreased by $0.3 \pm 0.08$-fold (Figure $1 \mathrm{c}$ and d, $p<0.01$ by sample $t$-test $v s$ zero, $n=14$ ). Figure 1e suggests that this effect was a consequence to the increase in firing $f$, as the $\mathrm{CV}_{\text {ISI }}$ was inversely related to basal firing $f$, both in the absence and presence of ethanol.

\section{Ethanol Increases Firing Frequency and Regularity of Spontaneous Firing in Presence of Neurotransmitter Receptor Antagonists}

The role of ionotropic and metabotropic neurotransmitter receptors in the ethanol-induced increase of GoC firing was characterized in the loose-patch cell-attached configuration. These experiments tested the possibility that ethanol increases $\mathrm{GoC}$ firing $f$ indirectly through modulation of excitatory and/or inhibitory inputs mediated by these neurotransmitter receptors. The following receptor antagonists were added to the ACSF: $10 \mu \mathrm{M}$ gabazine $\left(\mathrm{GABA}_{\mathrm{A}} \mathrm{R}\right)$, $1 \mathrm{mM}$ kynurenic acid (ionotropic glutamate receptors), $50 \mu \mathrm{M}$ D,L-APV (NMDA receptors), $1 \mu \mathrm{M}$ strychnine (glycine receptors), $10 \mu \mathrm{M}$ CGP $54626\left(\mathrm{GABA}_{\mathrm{B}} \mathrm{Rs}\right)$, and $1 \mu \mathrm{M} \mathrm{LY}$ 341495 (type-2 metabotropic glutamate receptors). In presence of these agents, the basal firing $f$ was $3 \pm 0.4 \mathrm{~Hz}(n=13$; not significantly different from firing $f$ in the absence of blockers by unpaired $t$-test), and ethanol $(40 \mathrm{mM})$ significantly increased it by $1 \pm 0.2 \mathrm{~Hz}$ (Figure $2 \mathrm{a}$ and $\mathrm{b} ; p<0.01$ by one-sample $t$-test $v s$ zero). We tested whether a change in osmolarity could account for the ethanol-induced increase in firing $f$. Urea is the agent of choice for this type of control experiment, because it has similar membrane permeability as ethanol (Widmer et al, 1998). In presence of the neurotransmitter receptor antagonist cocktail, urea 
a

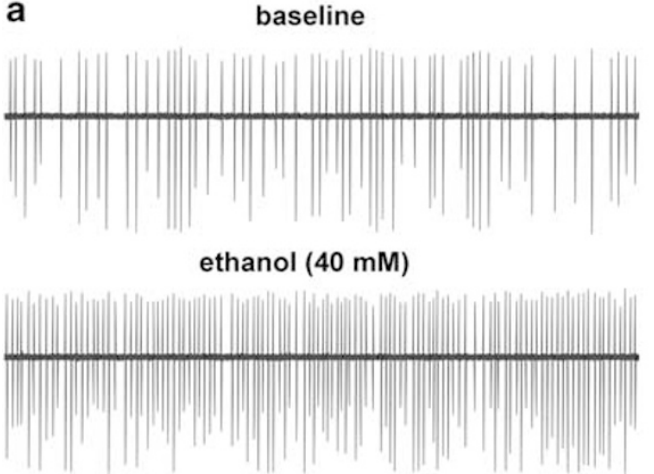

washout

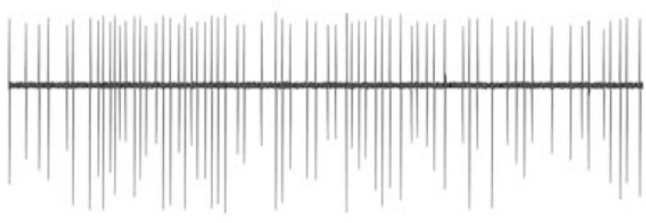

b

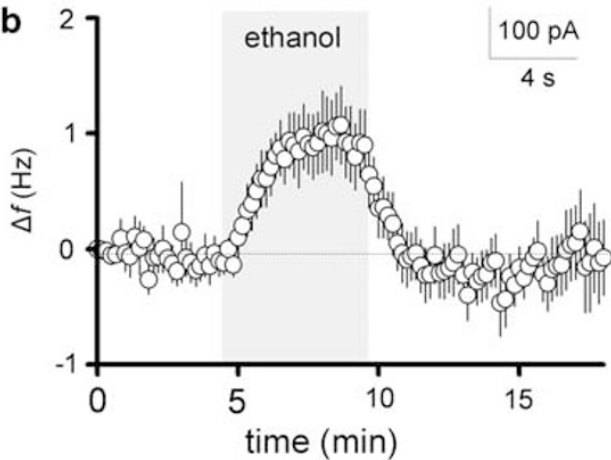

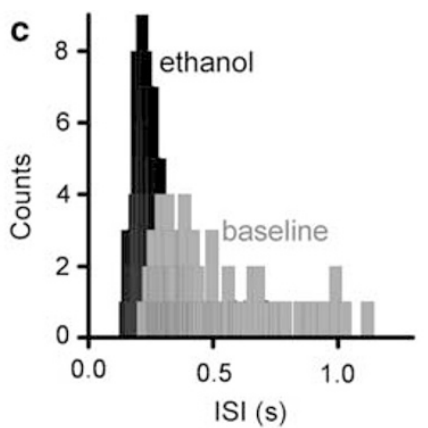

d
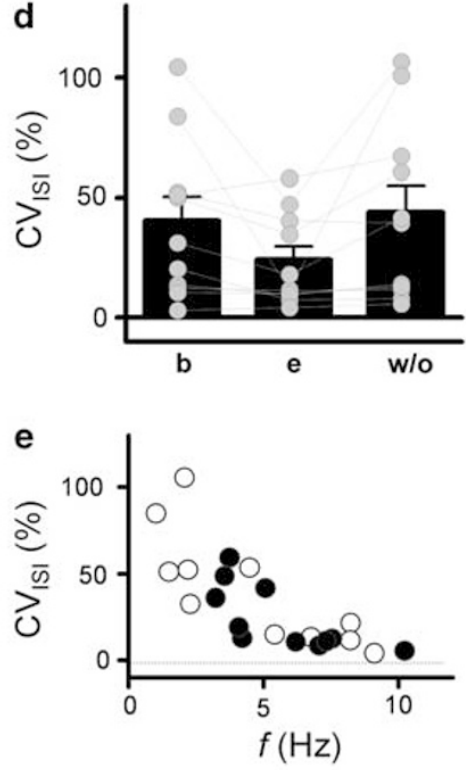

Figure I Ethanol increases frequency and regularity of spontaneous GoC firing. (a) Sample traces illustrating the effect of ethanol (40 $\mathrm{mM}$ ) on GoC firing recorded in the loose-patch cell-attached configuration. (b) Time course of the ethanol-induced firing frequency change $(\Delta f)$ normalized to the zero time point. Ethanol perfusion is represented by the gray bar (bin size $=10 \mathrm{~s} ; n=1 \mathrm{I}$ ). (c) Histogram of spike counts vs the interspike interval (ISI) for the baseline and ethanol conditions (bin size $=20 \mathrm{~ms}$ ). (d) Scatter plot showing the $\mathrm{CV}_{|S|}$ under baseline (b), ethanol (e) and washout (w/o) conditions. (e) Plot of CV vs basal firing $f$ for baseline (open circles) and $40 \mathrm{mM}$ ethanol (closed circles).

$(40 \mathrm{mM})$ did not significantly increase the firing $f$ with respect to the average of control and washout (Figure $2 \mathrm{~b}$; $\Delta f=0.17 \pm 0.09 \mathrm{~Hz} ; p>0.05$ by one-sample $t$-test $v s$ zero; $n=13)$.

The effect of ethanol on GoC pacemaker activity was further characterized in presence of the above-described neurotransmitter receptor antagonists. In presence of these agents, the ethanol-induced firing $f$ increase was not significantly correlated with the basal $f$ (Figure $2 c ; p>0.05$ by Spearman's correlation). Figure $2 \mathrm{~d}$ shows that the effect of ethanol on GoC firing $f$ is dose-dependent.

\section{Ethanol Increased Spontaneous Firing Frequency and Depolarized the Membrane Potential in the Perforated- Patch Configuration}

The effect of ethanol on spontaneous firing of GoCs was assessed in the perforated patch-clamp technique in presence of all the neurotransmitter receptor antagonists mentioned above. Table 1 summarizes the electrophysiological properties of GoCs under these conditions. Values are comparable with those previously reported, with small differences that could be a consequence of the presence of the neurotransmitter receptor antagonist cocktail, and the fact that our experiments were performed at $32-33^{\circ} \mathrm{C}$ using perforated-patch configuration rather than room temperature $\left(20-24^{\circ} \mathrm{C}\right)$ using whole-cell patch-clamp configuration (Forti et al, 2006). Figure $3 \mathrm{a}, \mathrm{b}$ and Table 1 show that ethanol $(40 \mathrm{mM})$ significantly increased the firing $f$ and decreased the $\mathrm{CV}_{\text {ISI }}$ (Table $1 ; n=8$ ). The effect of ethanol on firing $f$ using the perforated-patch configuration (Table 1) was not statistically different from the loose-patch cellattached data shown in Figure $2 \mathrm{~b}(p>0.05$ by unpaired $t$-test). Figure $3 \mathrm{a}, \mathrm{b}$ and Table 1 show that ethanol $(40 \mathrm{mM})$ slightly but significantly decreased the AHP amplitude. Action potential peak, half-width, threshold, and rise time were not significantly affected by this concentration of ethanol (Table 1). Figure 3b shows that the time course of the effect of ethanol on firing $f$ and AHP are similar.

As ethanol could increase the firing $f$ and decrease the amplitude of the AHP, in part, by depolarizing the membrane potential, we assessed its effect on the membrane potential in presence of $0.5 \mu \mathrm{M}$ TTX and the neurotransmitter receptor blocking cocktail. In presence of TTX, 

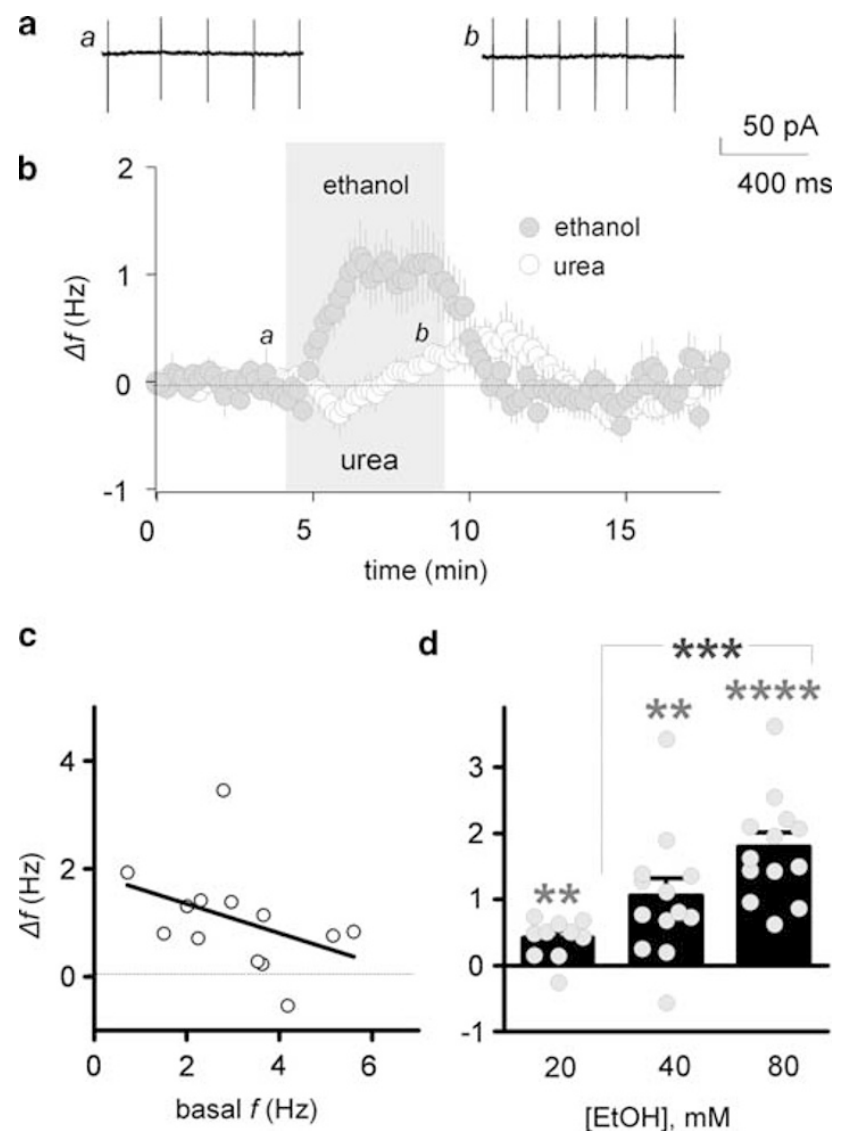

Figure 2 Ethanol increases frequency of spontaneous GoC firing in presence of neurotransmitter receptor antagonists. (a) Sample traces illustrating the effect of ethanol on firing. (b) Time course of the $40 \mathrm{mM}$ ethanol-induced $\Delta f$ (gray circles); the effect of urea ( $40 \mathrm{mM}$; white circles) on $\Delta f$ in presence is also shown, which was tested to determine whether ethanol acted through an osmotic mechanism ( $n=13$ in all cases). (c) Plot of the $40 \mathrm{mM}$ ethanol-induced $\Delta f$ vs basal $f$. (d) Dose-response curve for the ethanol-induced $\Delta f(20 \mathrm{mM}, n=10 ; 40 \mathrm{mM}, n=13$; and $80 \mathrm{mM}, n=13$; ** $p<0.0$ l, ****** $p<0.000$ I by one-sample $t$-test vs zero; $* * * * p<0.00$ I by one-way ANOVA followed Bonferroni post hoc test). All results shown in this figure were obtained in the loose-patch cell-attached configuration in presence of gabazine $(10 \mu \mathrm{M})$, kynurenate $(\mathrm{I} \mathrm{mM})$, D,L-APV $(50 \mu \mathrm{M})$, strychnine (I $\mu \mathrm{M})$, CGP 54626 (I $0 \mu \mathrm{M})$, and LY 34 I495 (I $\mu \mathrm{M})$.

neither action potentials nor any subthreshold membrane potential oscillations were observed (Figure 4a). Figure 4b, c and Table 1 show that ethanol $(40 \mathrm{mM})$ reversibly depolarized the membrane potential, with a similar time course of that of the ethanol-induced $\Delta f$. The effect of ethanol on the membrane potential was significantly correlated with the basal membrane potential $(p<0.05$ by linear regression; Figure 4d).

\section{Ethanol Does Not Significantly Affect the Firing Frequency or Membrane Potential Response to Current Injection}

Stimulation of excitatory afferent inputs can transiently depolarize the membrane potential and increase GoC firing (Kanichay and Silver, 2008; Watanabe and Nakanishi, 2003). To mimic the effect of these inputs, depolarizing current steps were injected to the $\mathrm{GoC}$ through the patch electrode;
Table I Modulation of Electrophysiological Properties of GoCs by Ethanol ( $40 \mathrm{mM})$

\begin{tabular}{lccl}
\hline Parameters & Baseline & $\begin{array}{c}\text { Change induced } \\
\text { by ethanol }\end{array}$ & p-value \\
\hline$f(\mathrm{~Hz})$ & $4 \pm 1$ & $0.77 \pm 0.2$ & $\mathbf{0 . 0 0 8}$ \\
$\mathrm{CV}_{\text {ISI }} \%$ (\%) & $41.5 \pm 12.7$ & $-19.07 \pm 3.2$ & $\mathbf{0 . 0 0 0 2}$ \\
Spike peak (mV) & $16.6 \pm 1.6$ & $-0.2 \pm 0.2$ & 0.41 \\
Spike half width (ms) & $0.56 \pm 0.03$ & $0.04 \pm 0.03$ & 0.27 \\
Spike threshold (mV) & $-67.6 \pm 5.4$ & $-0.01 \pm 0.3$ & 0.97 \\
Risel0-90 (ms) & $0.26 \pm 0.05$ & $-0.002 \pm 0.005$ & 0.63 \\
AHP time-to-peak (ms) & $18.3 \pm 1.2$ & $-0.03 \pm 0.23$ & 0.9 \\
AHP amplitude (mV) & $22.2 \pm 1.1$ & $-0.7 \pm 0.1$ & $\mathbf{0 . 0 0 0 2}$ \\
Estimated resting & $-76 \pm 3.4$ & $1.3 \pm 0.2$ & $\mathbf{0 . 0 0 0 6}$ \\
membrane potential $(\mathrm{mV})$ & & & \\
$R_{\text {in }}(\mathrm{M} \boldsymbol{\Omega})$ & $345.4 \pm 79$ & $2.6 \pm 8.1$ & 0.76 \\
\hline
\end{tabular}

In all cases $n=10$, except for the membrane potential $(n=9)$ and the $R_{\text {in }}$ $(n=7)$ data. Data were obtained in the perforated-patch mode in presence of ionotropic and metabotropic synaptic blockers. The $p$-values were calculated using one-sample $t$-test vs a theoretical mean of zero. Values are mean \pm SEM. Significant $p$-values are shown in bold.

these experiments were performed in the perforated-patch configuration in presence of the neurotransmitter receptor antagonist cocktail. Firing $f$ increased linearly as the amount of current injection increased and this relationship was not significantly affected by exposure to ethanol (Figure 5a and b; slopes were not significantly different by paired $t$-test; $n=7)$. In these experiments, ethanol increased the basal $f$ by $0.7 \pm 0.2 \mathrm{~Hz}(p<0.05$ by one-sample $t$-test $v s$ zero; $n=7)$, in agreement with the data shown in Figure 3 and Table 1.

The membrane potential response to current injection in presence of $0.5 \mu \mathrm{M}$ TTX was also investigated. Ethanol depolarized the membrane potential by $1.3 \pm 0.4 \mathrm{mV}$ $(p<0.05$ by one-sample $t$-test $v s$ zero; $n=5)$ in agreement with the data shown in Figure 4 and Table 1. The membrane potential changed linearly as the amount of depolarizing current injection increased and ethanol $(40 \mathrm{mM})$ did not significantly change this relationship (Figure $5 \mathrm{c}$ and $\mathrm{d}$; slopes were not significantly different by paired $t$-test; $n=5)$. Moreover, ethanol $(40 \mathrm{mM})$ did not affect the $R_{\text {in }}$, calculated from the voltage response to a single $350 \mathrm{~ms}$ current step of $-10 \mathrm{pA}$ (Table 1).

\section{Effect of Ethanol on the $\mathrm{Na}^{+} / \mathrm{K}^{+}$ATPase Current}

The transport of three $\mathrm{Na}^{+}$ions out of the cell and two $\mathrm{K}^{+}$ ions into the cell by the $\mathrm{Na}^{+} / \mathrm{K}^{+}$ATPase generates a net outward current that contributes to the maintenance of the resting membrane potential in neurons (for instance, see Genet and Kado, 1997) and acute exposure to ethanol has been shown to modulate the $\mathrm{Na}^{+} / \mathrm{K}^{+}$ATPase in preparations from rodent brains (Foley and Rhoads, 1994; Ledig et al, 1985; Syapin et al, 1985). We therefore assessed whether ethanol could affect $\mathrm{GoC}$ firing through modulation of the $\mathrm{Na}^{+} / \mathrm{K}^{+}$ATPase. We measured $\mathrm{Na}^{+} / \mathrm{K}^{+}$ATPase current using whole-cell voltage-clamp techniques under conditions in which currents mediated by $\mathrm{Ca}^{2+}, \mathrm{Na}^{+}$, and $\mathrm{K}^{+}$channels, as well as the $\mathrm{Na}^{+} / \mathrm{Ca}^{2+}$ exchanger, were 

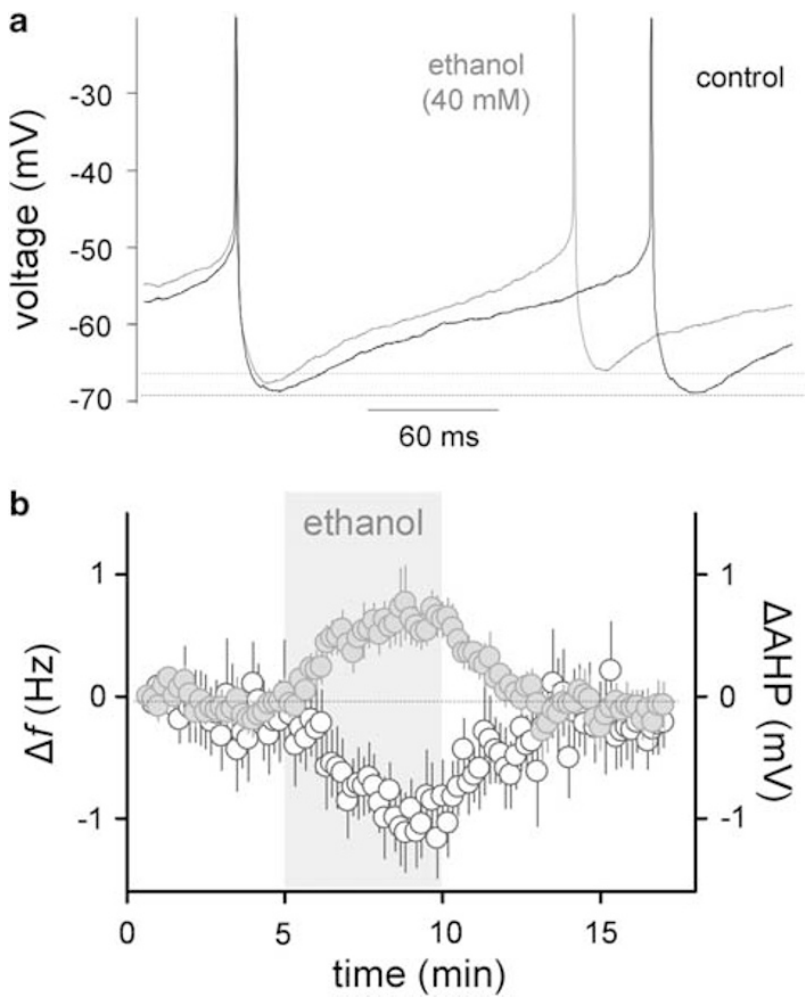

Figure 3 Ethanol increases spontaneous firing and decreases AHP amplitude in the perforated-patch configuration. (a) Representative trace illustrating that ethanol increases $f$ and slightly decreases the AHP (action potentials were truncated for clarity). (b) Time course of the ethanolinduced $\Delta f$ (gray circles) and $\Delta$ AHP (AHP peak amplitude change; white circles) $(n=8)$. Recordings were obtained in presence of gabazine $(10 \mu \mathrm{M})$, kynurenate (I mM), D,L-APV $(50 \mu \mathrm{M})$, strychnine (I $\mu \mathrm{M})$, CGP 54626 $(\mid 0 \mu M)$, and LY $34 \mid 495(\mid \mu M)$.

minimized or abolished (Hamada et al, 2003). The $\mathrm{Na}^{+} / \mathrm{K}^{+}$ ATPase currents were activated by a high pipette $\mathrm{Na}^{+}$ concentration. Figure 6 a shows an example of $\mathrm{Na}^{+} / \mathrm{K}^{+}$ ATPase current recording at $-25.1 \mathrm{mV}$; in this particular experiment, the holding current was $76.65 \mathrm{pA}$ and ethanol decreased it to $69.86 \mathrm{pA}$. On average, ethanol produced a reversible decrease of $5.1 \pm 1 \mathrm{pA}$ (percent change $=$ $3.24 \pm 0.72 \%$; $p<0.01$ by one-sample $t$-test $v$ sero; $n=6$ ) on the holding current (Figure $6 \mathrm{c}$ and $\mathrm{d} ; p<0.01$ by onesample $t$-test $v s$ zero). The amplitude of the $\mathrm{Na}^{+} / \mathrm{K}^{+}$ ATPase current was calculated by subtracting the holding current in the absence and presence of ouabain. This yielded a value of $167 \pm 36 \mathrm{pA}$, which was decreased by $3.28 \pm 0.72 \%$ by ethanol $(p<0.01$ by one-sample $t$-test $v s$ zero; $n=6)$. In presence of ouabain, ethanol did not significantly change the holding current, which is expected to be mainly mediated by leak conductances (Figure $6 \mathrm{~b}$ and e).

We next tested whether slight inhibition of the $\mathrm{Na}^{+} / \mathrm{K}^{+}$ ATPase with a low concentration of ouabain could mimic the effect of ethanol on GoC firing. In the whole-cell configuration, using the high $\mathrm{Na}^{+}$internal solution described above, 5 min bath application of $0.1 \mu \mathrm{M}$ ouabain produced a similar inward shift in the holding current to that produced by $40 \mathrm{mM}$ ethanol $(8 \pm 2 \mathrm{pA}, p<0.01$ by sample $t$-test $v s$ zero, $n=12$ ), with the exception that the ouabain effect was not reversible on washout (Figure $7 \mathrm{a}$ and $\mathrm{c}$ ). We then assessed the impact of $0.1 \mu \mathrm{M}$ ouabain on GoC firing in the loose-patch cell-attached configuration and found that it increased the firing $f$ by $0.9 \pm 0.13 \mathrm{~Hz}$ (Figure $7 \mathrm{~b}$ and $\mathrm{d}$; $p<0.001$ by one-sample $t$-test $v s$ zero; $n=8)$. The $0.1 \mu \mathrm{M}$ ouabain- and ethanol-induced changes in holding current and firing $f$ were similar (Figure $7 \mathrm{c}$ and $\mathrm{d}$ ). It should be noted that we attempted to determine whether a saturating concentration of ouabain $(1 \mathrm{mM})$ occluded the effect of ethanol on GoC firing; however, we found that it induced a significant depolarization of the membrane potential $(\triangle \mathrm{MP}=$ $71 \pm 32 \mathrm{mV} ; n=3$ ), leading to the inactivation of voltagegated $\mathrm{Na}^{+}$channels and cessation of GoC firing.

We also studied the effect of $\mathrm{Na}^{+} / \mathrm{K}^{+}$ATPase inhibition using the perforated-patch configuration. Figure $7 \mathrm{e}$ and $\mathrm{f}$ show that ouabain $(0.1 \mu \mathrm{M})$ decreased the AHP by $0.73 \pm 0.26 \mathrm{mV}(p<0.05$ by one-sample $t$-test $v s 0 ; n=6)$ and increased the firing $f$ by $0.87 \pm 0.32 \mathrm{~Hz}(p<0.05$ by onesample $t$-test $v s 0$; data not shown; $n=6)$. The other action potential waveform parameters were not significantly altered by $5 \mathrm{~min}$ of ouabain application. In Figure $7 f$, data from Figure $3 b$ is shown again for comparison. Note the similar onset time course for the effect of ouabain and ethanol on firing $f$ and AHP amplitude.

Inhibition of the $\mathrm{Na}^{+} / \mathrm{K}^{+}$ATPase by ouabain was tested in the GoC computer model. Modeling of the effects of increasing concentrations of ouabain on $\mathrm{Na}^{+} / \mathrm{K}^{+}$ATPase is shown in Supplementary Figure $1 \mathrm{~B}$, wherein ouabain had an $\mathrm{IC}_{50}$ of $\sim 0.6 \mu \mathrm{M}$ and a concentration of $0.1 \mu \mathrm{M}$ inhibited $\mathrm{Na}^{+} / \mathrm{K}^{+}$ATPase function by $\sim 15 \%$. Figure $7 \mathrm{~g}$ shows that a $15 \%$ reduction in $\mathrm{Na}^{+} / \mathrm{K}^{+}$ATPase function in the model increases the GoC spontaneous firing rate $(\sim 1 \mathrm{~Hz})$ and decreases the AHP $(\sim 1 \mathrm{mV}$; represented by the difference between the two dashed lines) to a similar extent as in the slice experiments with $0.1 \mu \mathrm{M}$ ouabain and $40 \mathrm{mM}$ ethanol (see also Supplementary Figure 1C). The simulated effect of higher concentrations of ouabain on the firing $f$ is summarized Figure $7 \mathrm{~h}$ and Supplementary Figure 1C.

In presence of $0.5 \mu \mathrm{M}$ TTX, ouabain $(0.1 \mu \mathrm{M})$ depolarized the membrane potential by $1.7 \pm 0.4 \mathrm{mV}$ at $t=5 \mathrm{~min}$ after the start of ouabain application $(p<0.01$ by one-sample $t$-test $v s$ zero; $n=8)$ without significantly changing $R_{\text {in }}$ calculated from the voltage response to a single $350 \mathrm{~ms}$ current step of $-10 \mathrm{pA}(101.5 \pm 2.2 \%$ of control, $p>0.05$ by one-sample $t$-test $v s 100 ; n=8$ ) (Figure $8 \mathrm{a}$ and $\mathrm{b}$ ). In Figure $8 \mathrm{~b}$, the effect of ethanol on the membrane potential from Figure $4 \mathrm{c}$ is shown again for comparison. Note the similar onset time course for the effect of ouabain and ethanol on the membrane potential.

The effect of ouabain in the absence of $\mathrm{Na}^{+}$channel currents - to mimic experiments carried out in TTX - was also studied in the computer model. Simulation of the effect of $0.1 \mu \mathrm{M}$ ouabain depolarized the membrane potential by $\sim 1 \mathrm{mV}$ and it only slightly affected $R_{\text {in }}$ (control $=159 \mathrm{M} \Omega$ and ouabain $=156 \mathrm{M} \Omega$; calculated from the the voltage response to a single $350 \mathrm{~ms}$ current step of $-10 \mathrm{pA}$ ) (Figure 8c). The effect of higher concentrations of ouabain on the membrane potential is shown in Figure $8 \mathrm{~d}$ and Supplementary Figure 1D. Supplementary Figure 2 shows that simulation of the effect of $0.1 \mu \mathrm{M}$ ouabain did not affect the firing frequency or membrane potential response to current injection in the GoC model; these findings are in agreement with those shown in Figure 5. 

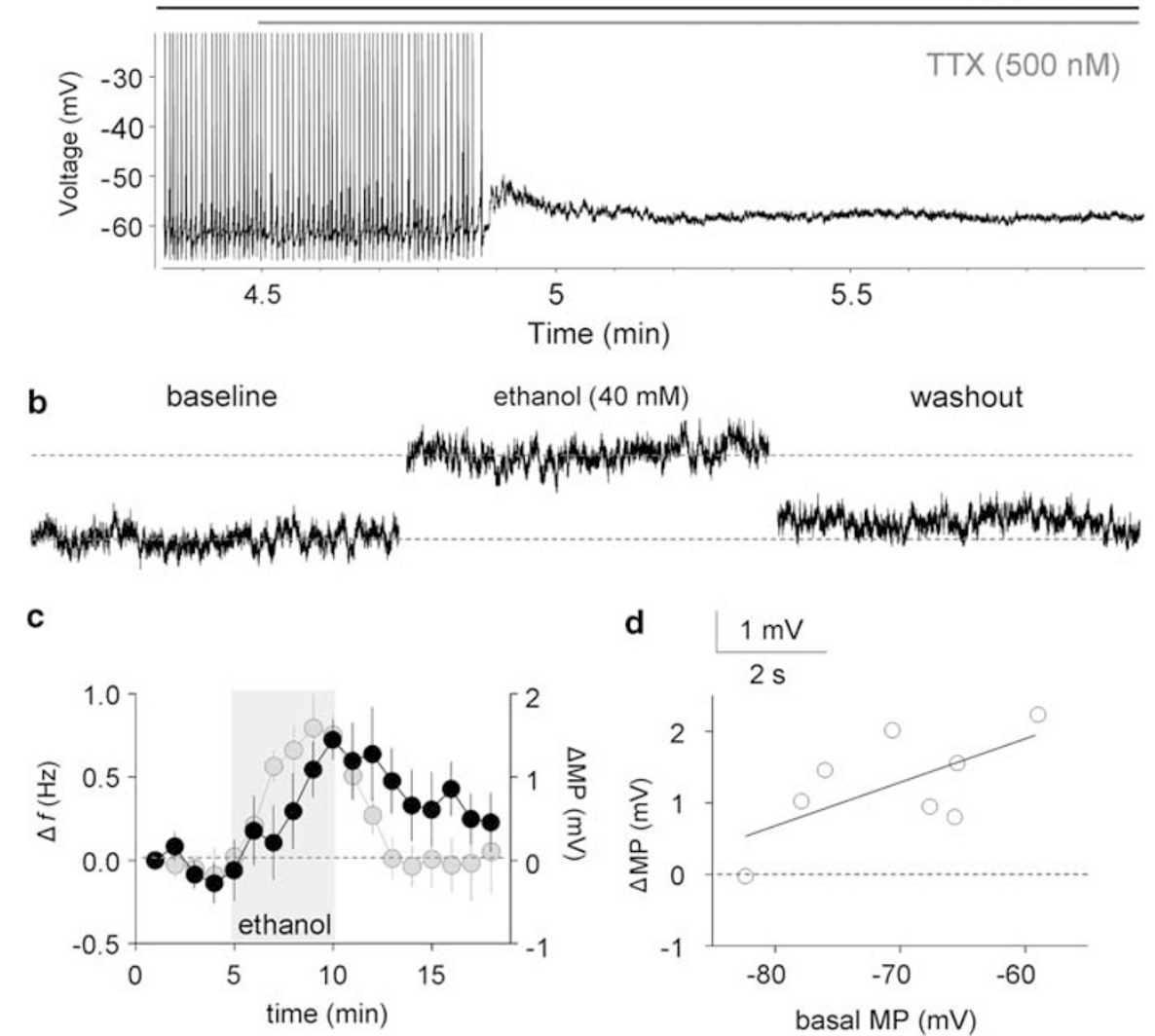

Figure 4 Ethanol depolarizes the membrane potential. (a) Effect of TTX on spontaneous GoC firing (action potentials were truncated for clarity). (b) Representative traces illustrating the ethanol-induced membrane potential depolarization. (c) Time course of the ethanol-induced membrane potential (MP) change (black circle; bin size $=I \mathrm{~min} ; n=8$ ). The time course of the ethanol-induced $\Delta f$ (gray circles) from Figure $3 b$ is shown again for comparison (bin size $=I \min ; n=8)$. (d) Plot of the ethanol-induced membrane potential change vs basal membrane potential. All these recordings were made in the perforated-patch current-clamp configuration ( $\left.\left.\right|_{\text {holding }}=0\right)$. Recordings were obtained in presence of gabazine $(I 0 \mu M), k y n u r e n a t e ~(I ~ m M), ~ D, L-A P V$ (50 $\mu \mathrm{M})$, strychnine (I $\mu \mathrm{M})$, CGP 54626 (I0 $\mu \mathrm{M})$, LY $34 \mid 495$ (I $\mu \mathrm{M})$, and TTX $(0.5 \mu \mathrm{M})$.

\section{DISCUSSION}

The purpose of this study was to characterize the mechanism by which ethanol excites cerebellar GoCs. Our findings can be summarized as follows: (1) ethanol increased spontaneous GoC firing $f$ and decreased the $\mathrm{CV}_{\text {ISI }}$ independently of extrinsic inputs mediated by several ionotropic and metabotropic neurotransmitter receptors; (2) the effect of ethanol was independent of the basal firing $f$ and was dose dependent; (3) ethanol decreased the AHP amplitude and caused membrane potential depolarization; and (4) ethanol did not significantly affect the GoC $R_{\text {in }}$ calculated from the voltage response to a single hyperpolarizing pulse and neither affected the firing frequency nor the membrane potential response to current injection, further confirming that it lacks a significant effect on $R_{\text {in }}$. These findings support the hypothesis that ethanol increases $\mathrm{GoC}$ firing directly by modulating an intrinsic nonion channel target that controls pacemaker activity of these neurons.

The $\mathrm{Na}^{+} / \mathrm{K}^{+}$ATPase was considered as a potential nonion channel ethanol target, because its electrogenic properties have been shown to have a role in controlling spontaneous firing, membrane potential, and membrane potential hyperpolarization in neurons (Genet and Kado,
1997; Kim et al, 2007; Munakata et al, 1998; Pulver and Griffith, 2010; Thompson and Prince, 1986; Wang and Huang, 2006). In addition, studies from several laboratories have shown inhibition of the $\mathrm{Na}^{+} / \mathrm{K}^{+}$ATPase by acute ethanol exposure using brain homogenates, synaptosomes, microsomes, or cultured neurons (Foster et al, 1989; Israel et al, 1965; Ledig et al, 1985; Rangaraj and Kalant, 1982; Swann, 1983; Syapin and Alkana, 1986; but see Foley and Rhoads, 1994). The precise mechanism responsible for this inhibitory effect of ethanol is currently unknown, but may be, in part, a consequence of stabilization of the ATP-bound state and impairment in the formation of the $\mathrm{K}^{+}$-sensitive conformational state of the enzyme (Swann, 1983). In general agreement with these studies, we found that $\mathrm{Na}^{+} / \mathrm{K}^{+}$ATPase currents were slightly but significantly inhibited by ethanol in a ouabain-sensitive manner. A submaximal concentration of ouabain, which produced equivalent inhibition of the $\mathrm{Na}^{+} / \mathrm{K}^{+}$ATPase current as ethanol, increased spontaneous action potential firing, depolarized the membrane potential, and decreased the AHP in GoCs. Unlike ethanol, the effect of ouabain on these parameters was irreversible, which is in agreement with the literature and is expected because of the high affinity of this agent for the $\mathrm{Na}^{+} / \mathrm{K}^{+}$ATPase (Genet and Kado, 1997; Kim et al, 2007). The onset of the effect of ethanol on $\mathrm{Na}^{+} / \mathrm{K}^{+}$ 

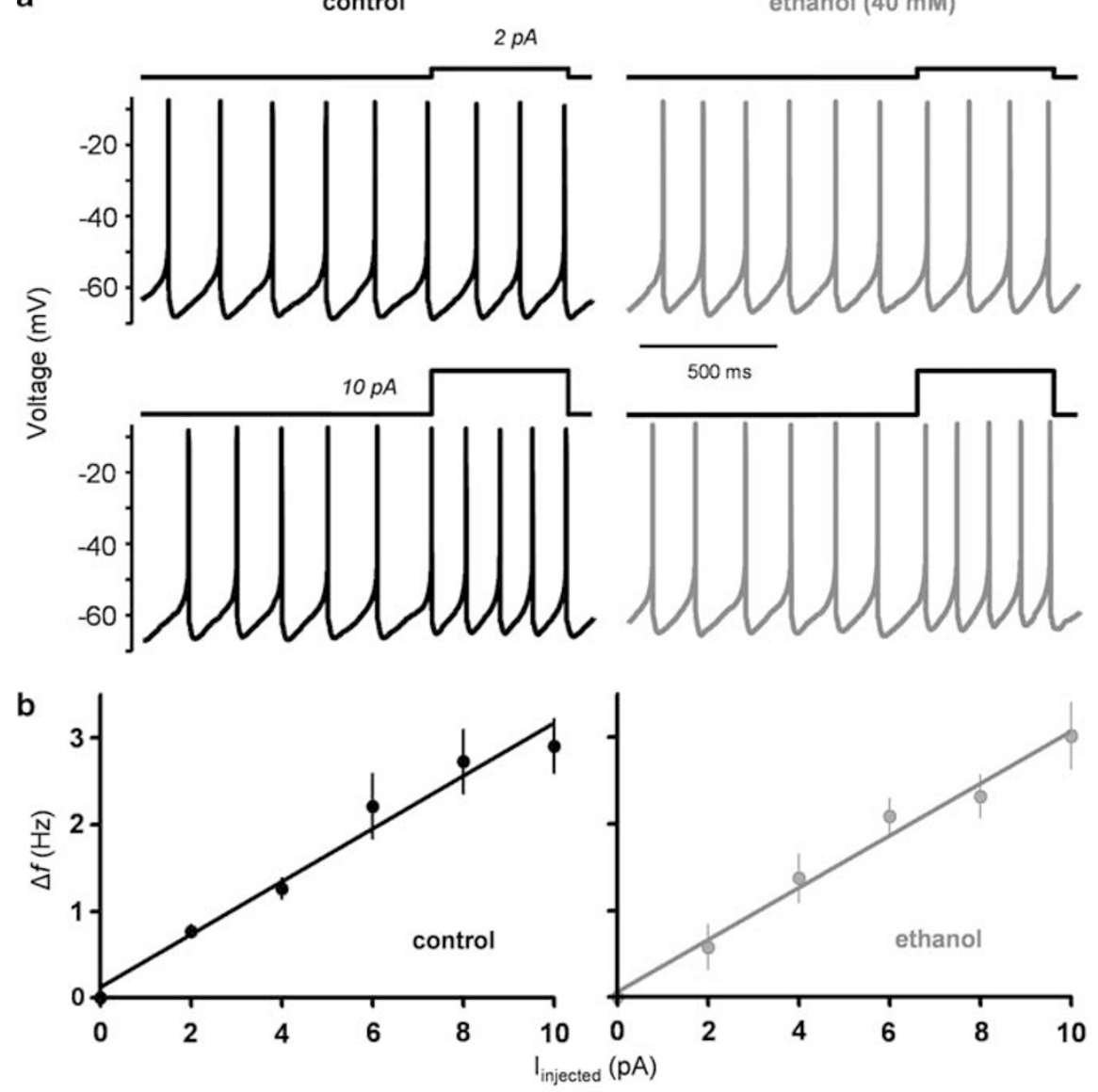

C

control

ethanol $(40 \mathrm{mM})$
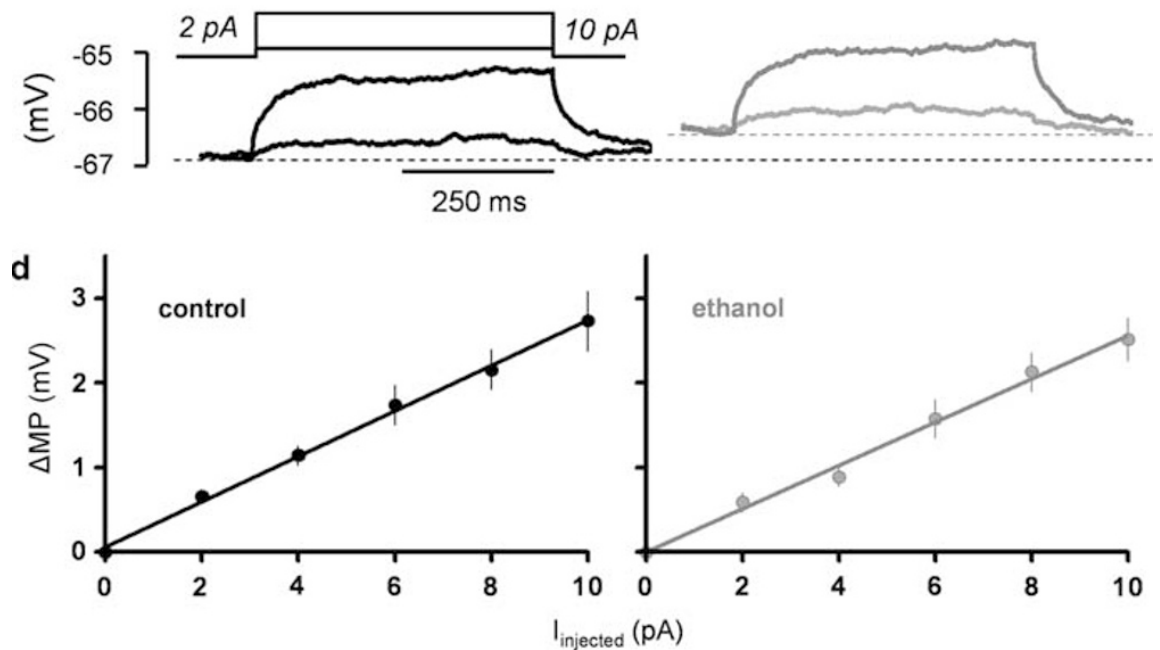

Figure 5 Ethanol does not significantly affect the firing frequency and the membrane potential response to current injection. (a) Representative traces illustrating the changes in $\mathrm{GoC}$ firing activity that were elicited by steps of depolarizing current injection ( 2 and $10 \mathrm{pA}, 500 \mathrm{~ms}$ square steps) in the absence (control) and presence of ethanol. (b) Average GoC current-frequency plots obtained under control conditions and in presence of $40 \mathrm{mM}$ ethanol ( $n=7$ ). (c) Representative traces illustrating the changes in the membrane potential (MP) of GoCs that were elicited by steps of depolarizing current injection (2 and 10 pA, 500 ms square steps) in the absence (control) and presence of ethanol. (d) Average GoC current-MP plots obtained under control conditions and in presence of $40 \mathrm{mM}$ ethanol $(n=5)$. All results shown in this figure were obtained in the perforated-patch current-clamp configuration in presence of

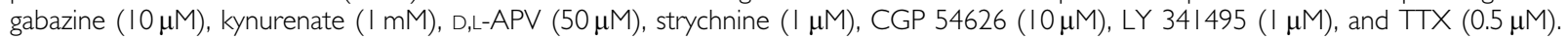

ATPase current, membrane potential, and AHP matched closely to that of ouabain. The onset of the effect of ethanol on $\mathrm{GoC}$ firing frequency measured in the loose-patch cell-attached configuration was slightly faster than that of ouabain (Figure 7d), suggesting that another target could be involved in the initial phase of this effect of ethanol. 

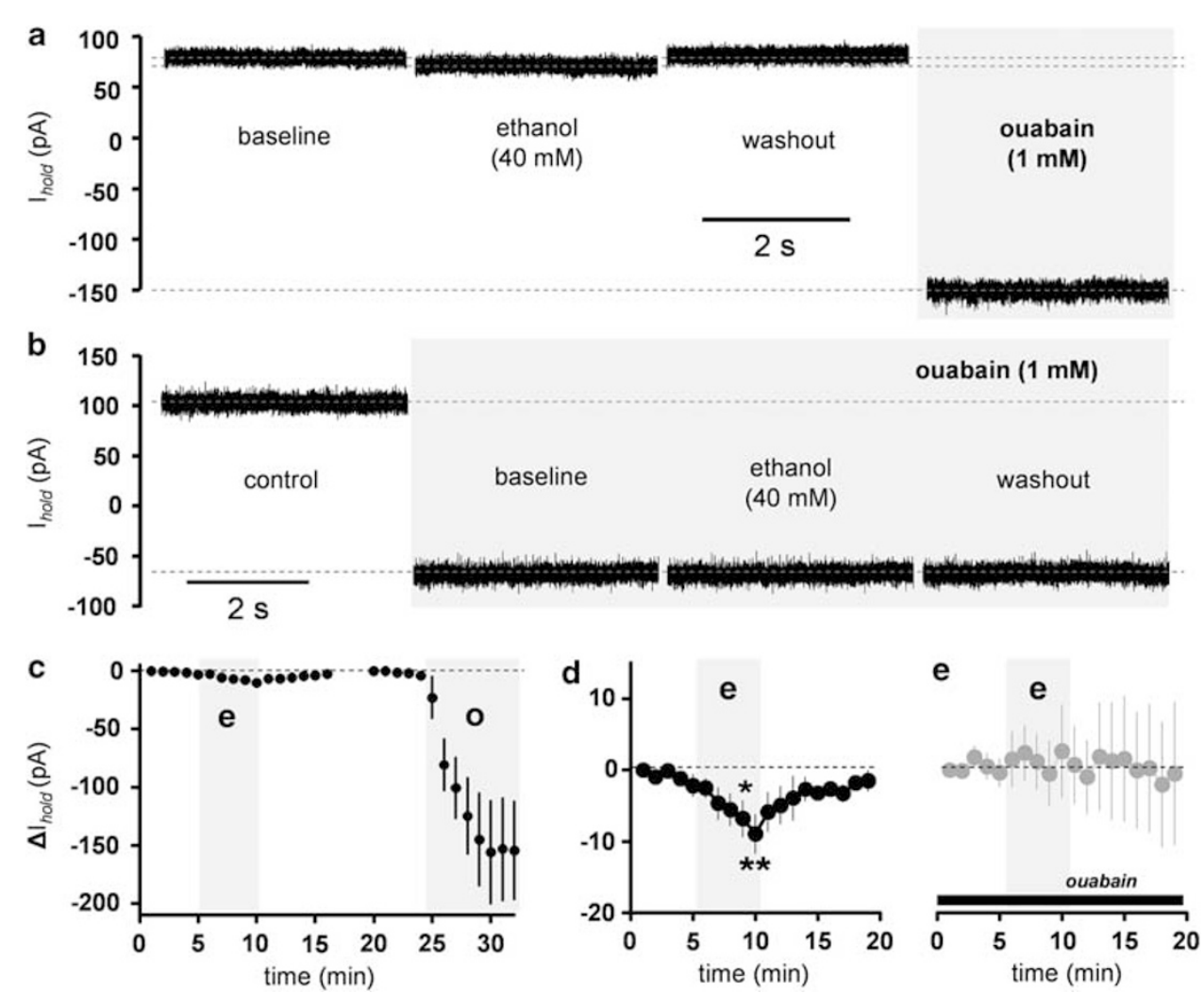

Figure 6 Ethanol inhibits the $\mathrm{Na}^{+} / \mathrm{K}^{+}$ATPase current. (a) Representative whole-cell voltage-clamp recording traces illustrating the effect of ethanol on the $\mathrm{Na}^{+} / \mathrm{K}^{+}$ATPase current. (b) Ethanol does not affect the leak current recorded in presence of ouabain. (c) Time course graph illustrating the effect of ethanol (e) and ouabain (o) on the holding current $(n=6)$. The gray bar represents the $5 \mathrm{~min}$ application of ouabain or ethanol. (d) Time course of the effect of ethanol on the $\mathrm{Na}^{+} / \mathrm{K}^{+}$ATPase current shown at an expanded scale ${ }^{*} p<0.05$, ${ }^{*} \mathrm{*} p<0.0$ l by one-way repeated-measures ANOVA followed by Bonferroni post hoc posttest). (e) Time course of the effect of ethanol on leak currents recorded in presence of I mM ouabain (black bar). Ethanol perfusion is represented by the gray bar (bin size $=1 \mathrm{~min}$ ). In all cases, bin size $=1 \mathrm{~min}$.

However, the time course of the effects of ouabain and ethanol were very similar in the perforated-patch configuration (Figure 7f), indicating that inhibition of the $\mathrm{Na}^{+} / \mathrm{K}^{+}$ATPase has a central role in the mechanism of action of ethanol.

The hypothesis that ethanol increases GoC excitability through inhibition of the $\mathrm{Na}^{+} / \mathrm{K}^{+}$ATPase was quantitatively tested using computer modeling. These studies were carried out using a GoC model that faithfully reproduces the electrophysiological characteristics of GoCs. Incorporation of the $\mathrm{Na}^{+} / \mathrm{K}^{+}$ATPase into the model did not change GoC responsiveness or tonic firing. Simulation of the effect of $\mathrm{Na}^{+} / \mathrm{K}^{+}$ATPase block with ouabain produced the expected dose-dependent changes in GoC function: (1) increase in spike rate, (2) decrease in AHP, and (3) depolarization of the membrane potential. The effect of $0.1 \mu \mathrm{M}$ ouabain on these parameters was strikingly similar to that observed in the slice experiments and, in agreement with the slice data, this concentration of ouabain minimally changed the $R_{\text {in }}$. Taken together with the experimental results, these computer modeling findings indicate that the $\mathrm{Na}^{+} / \mathrm{K}^{+}$ ATPase controls GoC excitability and that inhibition of this electrogenic pump can explain the mechanism of action of ethanol on GoCs. Because of the success of the minimal model we describe here, no further elaborations were attempted, such as including additional pumps or the $\mathrm{Na}^{+}$/ $\mathrm{Ca}^{2+}$ exchanger.
Acute exposure to either $40 \mathrm{mM}$ ethanol or $0.1 \mu \mathrm{M}$ ouabain significantly decreased the amplitude of the AHP and depolarized the membrane potential, and these effects could be, in part, responsible for the ethanol-induced increase in spontaneous action potential firing of GoCs (Cloues and Sather, 2003). These effects are similar to those previously reported by Brodie and Appel (1998) in VTA dopaminergic neurons, in which $80 \mathrm{mM}$ ethanol produced $\sim 1 \mathrm{mV}$ decrease in the AHP peak amplitude and also a $\sim 1 \mathrm{mV}$ membrane potential depolarization. Decreases in AHP amplitude have also been observed in dentate granule and CA3 pyramidal neurons (Niesen et al, 1988; Siggins et al, 1987). Recently, ethanol ( 30 and $50 \mathrm{mM}$ ) was found to decrease the slow AHP decay time constant and this effect was more pronounced in neurons from peri-adolescent (P30-40) than adult (P70-80) Sprague-Dawley rats (Yan et al, 2009). Future studies should assess whether ethanolinduced inhibition of the $\mathrm{Na}^{+} / \mathrm{K}^{+}$ATPase could contribute to the effects of ethanol on the AHP and membrane potential in neurons other than GoCs. Ethanol may not consistently inhibit the ATPase, leading to depolarization of the membrane potential in all neuronal populations. This could be a consequence of differences in expression of $\mathrm{Na}^{+}$/ $\mathrm{K}^{+}$ATPase isoforms or distinct regulation of pump activity by intracellular signaling pathways (Richards et al, 2007).

The finding that the spontaneous firing of GoCs is increased by ethanol places these interneurons among other 
a
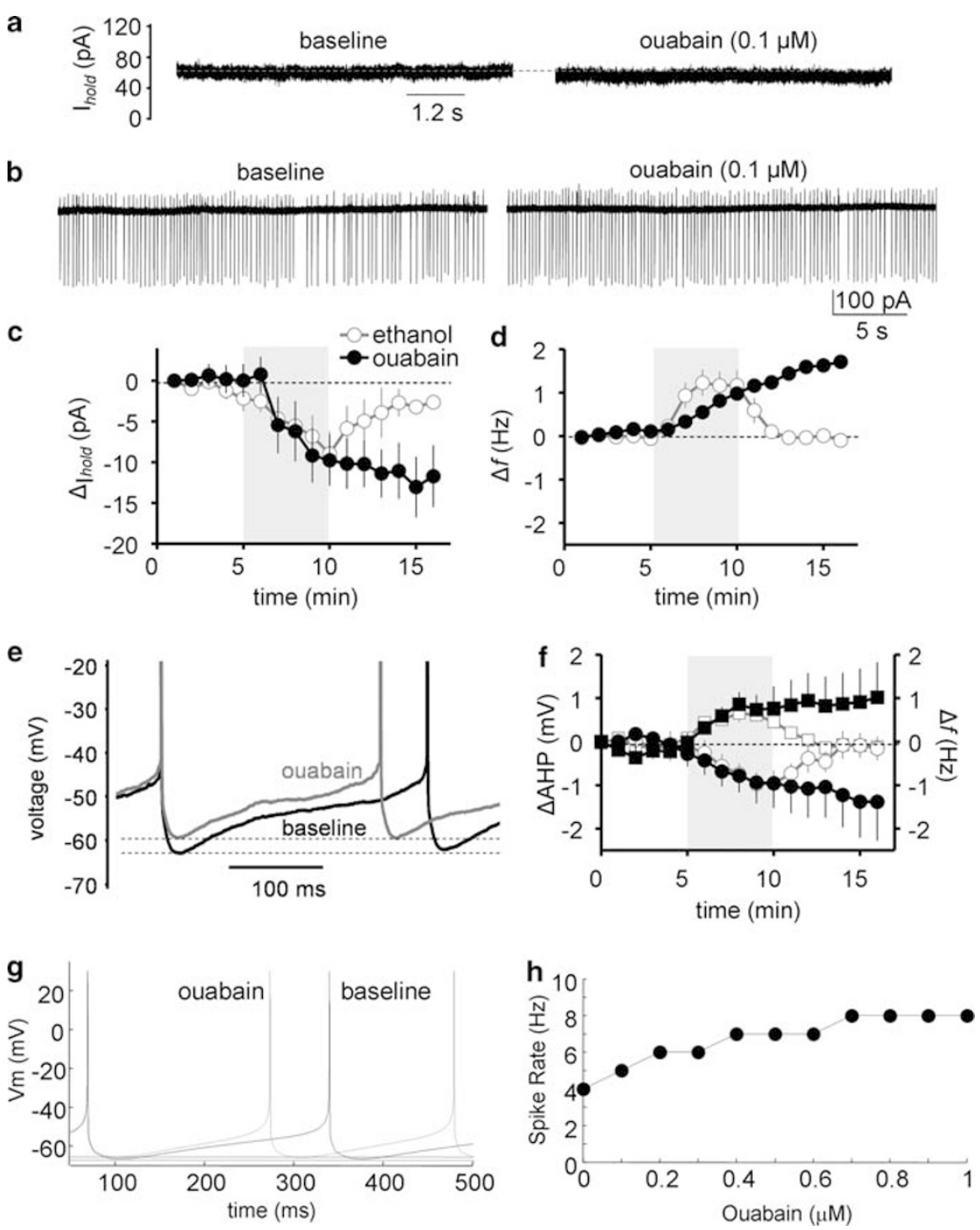

Figure 7 Ouabain mimics the effect of ethanol on firing. (a) Representative whole-cell voltage-clamp recording traces illustrating that a low concentration of ouabain produces similar inhibition of the $\mathrm{Na}^{+} / \mathrm{K}^{+}$ATPase current to that produced by $40 \mathrm{mM}$ ethanol. (b) Representative loose-patch cell-attached recording traces illustrating that $0.1 \mu \mathrm{M}$ ouabain slightly increases spontaneous action potential firing of GoCs. (c) Time course graph illustrating the effect of $0.1 \mu \mathrm{M}$ ouabain on the holding current (black circles) in whole-cell voltage-clamp; the effect of $40 \mathrm{mM}$ ethanol from Figure $6 \mathrm{~d}$ is shown again for comparison (white circles). (d) Time course graph illustrating the change in spontaneous firing $\mathrm{f}$ of GoCs induced by $0.1 \mu \mathrm{M}$ ouabain (black circles) in the loose-patch cellattached configuration; the effect of $40 \mathrm{mM}$ ethanol from Figure $2 b$ is shown again for comparison (white circles). (e) Representative traces recorded in the perforated-patch configuration illustrating the increase in firing $f$ and the decrease in AHP amplitude induced by ouabain. ( $f$ ) Time course graph illustrating the change in firing $f$ (black squares) and AHP amplitude (black circles) of GoCs induced by $0.1 \mu \mathrm{M}$ ouabain in the perforated-patch configuration; the effect of $40 \mathrm{mM}$ ethanol on firing $f$ (white squares) and AHP (white circles) from Figure $3 \mathrm{~b}$ is shown again for comparison. (g) Computer simulation of the effect of $0.1 \mu \mathrm{M}$ ouabain on GoC firing. (h) Computer simulation of the effect of increasing concentrations of ouabain on spontaneous action potential firing in GoCs.

pacemaker neurons that are excited by this substance of abuse. Ethanol has been shown to increase spontaneous firing of substantia nigra, CA3 pyramidal, and inferior olivary neurons by unknown mechanisms (Bloom and Siggins, 1987; Galindo et al, 2005; Mereu et al, 1984; Rogers et al, 1986). Ethanol produces a similar effect on VTA dopaminergic neurons and this is, at least in part, mediated by inhibition of a quinidine-sensitive $\mathrm{K}^{+}$current and/or potentiation of $I_{\mathrm{h}}$ (Appel et al, 2003; Okamoto et al, 2006). Ethanol also excites stratum radiatum-lacunosum moleculare hippocampal interneurons and molecular layer interneurons in the cerebellum by potentiating $I_{\mathrm{h}}$ (Hirono et al, 2009; Yan et al, 2009). Importantly, we investigated the role of $I_{\mathrm{h}}$, several $\mathrm{K}^{+}$channel-mediated currents $\left(I_{\mathrm{A}}, I_{\mathrm{M}}\right.$, delayed rectifier- and SK channel-mediated currents), and persistent sodium channel currents in the mechanism of action of ethanol at GoCs; we found no evidence indicating that these currents mediate the ethanol-induced increase of GoC firing (Botta P, Sangrey T, De Schutter E, and Valenzuela CF, unpublished observations). Taken together with our results, these findings indicate that ethanol can increase firing of several neuronal populations across the brain through a variety of mechanisms. However, the potential contribution of $\mathrm{Na}^{+} / \mathrm{K}^{+}$ATPase inhibition in the actions of ethanol at the above-mentioned pacemaker neurons should be investigated. 
a

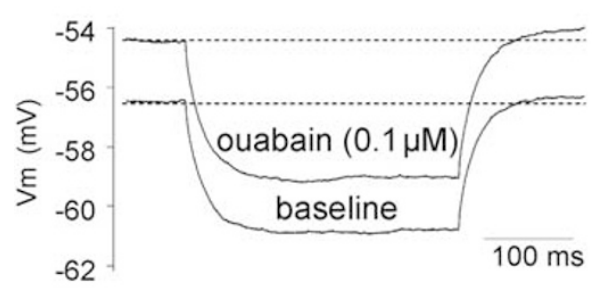

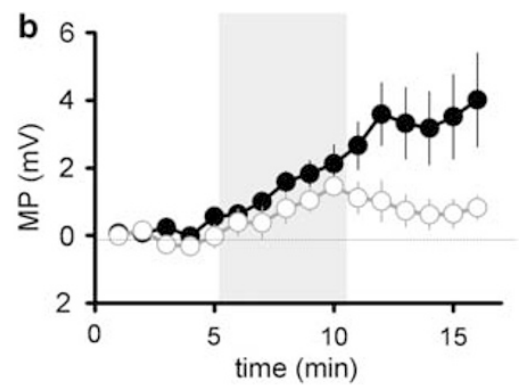
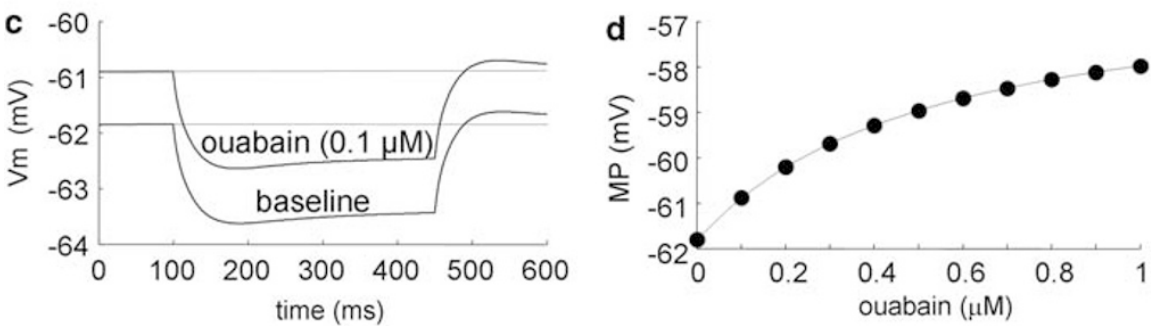

Figure 8 Ouabain mimics the effect of ethanol on the membrane potential. (a) Representative traces recorded in perforated-patch configuration illustrating the ouabain-induced depolarization of the membrane potential (MP); the $R_{\text {in }}$ was monitored with a $350 \mathrm{~ms}$ current step of - I0 pA and it was not affected by ouabain. (b) Time course graph illustrating the change in membrane potential induced by $0.1 \mu M$ ouabain (black circles) in the perforated-patch configuration; the effect of $40 \mathrm{mM}$ ethanol on the membrane potential from Figure $4 \mathrm{c}$ is shown again for comparison (white circles). The gray bar represents the $5 \mathrm{~min}$ application of ouabain or ethanol. In all cases, bin size $=1 \mathrm{~min}$. (c) Computer simulation of the effect of $0.1 \mu \mathrm{M}$ ouabain on the GoC membrane potential; ouabain minimally affected the $R_{\text {in }}$, as monitored by a 350 ms current step of $-10 \mathrm{pA}$. (d) Computer simulation of the effect of increasing concentrations of ouabain on the membrane potential in GoCs.

The increase in spontaneous $\mathrm{GoC}$ firing caused by $\mathrm{Na}^{+} / \mathrm{K}^{+}$ATPase inhibition is likely responsible, at least in part, for the increase in spontaneous action potentialdependent GABA release at $\mathrm{GoC}-\mathrm{GrC}$ synapses and the increase in tonic GABAergic currents in GrCs (Carta et al, 2004; Hanchar et al, 2005). These findings are in general agreement with those of Richards et al (2007), who reported that $\mathrm{Na}^{+} / \mathrm{K}^{+}$ATPase inhibition in interneurons increases sIPSC frequency in pyramidal neurons of the subiculum. The ultimate consequences of the $\mathrm{EtOH}$-induced increase of GABA release from GoCs are decreased GrC excitability and de-afferentiation of the cerebellar cortex from mossy fiber inputs (Huang and Huang, 1992, 2007). Inhibition of glutamatergic transmission at mossy fiber-GrC synapses is unlikely to contribute to the mechanism of action of ethanol, as AMPA and NMDA receptor-mediated currents seem to be minimally affected by sub-anesthetic concentrations of ethanol in GrCs (Carta et al, 2004; Offenhauser et al, 2006).

Computer modeling studies predicted that the GoC-GrC feedback loop causes oscillations in the GrC layer with a characteristic frequency restricted to the $10-40 \mathrm{~Hz}$ range ( $\beta$ oscillations), which may be involved in cerebrocerebellar communication during sensory processing and movements (Maex and De Schutter, 2005; Soteropoulos and Baker, 2006). A recent study showed that GoCs are extensively connected through gap junctions, which drive low-frequency oscillatory synchronization and rhythmic inhibition of GrCs; importantly, in vivo electrophysiological studies showed synchronization between GoC firing and low-frequency local field potential oscillations in the cerebellar cortex during quiet wakefulness (Dugue et al, 2009). Therefore, ethanol-induced increases in spontaneous action potential firing of GoCs may impair oscillatory activity, leading to alterations, not only in motor coordination but also in several cognitive processes. Future studies should examine the long-term effects of ethanol on the function of the $\mathrm{GrC}$ layer neuronal network and their potential contribution to the pathophysiology of alcoholism.

\section{ACKNOWLEDGEMENTS}

We thank LD Partridge for critically reading the paper. This study is supported by RO1-AA014973 and by OISTPC.

\section{DISCLOSURE}

The authors declare no conflict of interest.

\section{REFERENCES}

Appel SB, Liu Z, McElvain MA, Brodie MS (2003). Ethanol excitation of dopaminergic ventral tegmental area neurons is blocked by quinidine. J Pharmacol Exp Ther 306: 437-446.

Bloom FE, Siggins GR (1987). Electrophysiological action of ethanol at the cellular level. Alcohol 4: 331-337.

Botta P, Mameli M, Floyd KL, Radcliffe RA, Valenzuela CF (2007a). Ethanol sensitivity of GABAergic currents in cerebellar granule neurons is not increased by a single amino acid change (R100Q) in the alpha6 GABAA receptor subunit. J Pharmacol Exp Ther 323: 684-691.

Botta P, Radcliffe RA, Carta M, Mameli M, Daly E, Floyd KL et al (2007b). Modulation of GABA(A) receptors in cerebellar granule neurons by ethanol: a review of genetic and electrophysiological studies. Alcohol 41: 187-199.

Brodie MS, Appel SB (1998). The effects of ethanol on dopaminergic neurons of the ventral tegmental area studied 
with intracellular recording in brain slices. Alcohol Clin Exp Res 22: 236-244

Brodie MS, Pesold C, Appel SB (1999). Ethanol directly excites dopaminergic ventral tegmental area reward neurons. Alcohol Clin Exp Res 23: 1848-1852.

Carta M, Mameli M, Valenzuela CF (2004). Alcohol enhances GABAergic transmission to cerebellar granule cells via an increase in Golgi cell excitability. J Neurosci 24: 3746-3751.

Cheron G, Servais L, Dan B (2008). Cerebellar network plasticity: from genes to fast oscillation. Neuroscience 153: 1-19.

Cloues RK, Sather WA (2003). Afterhyperpolarization regulates firing rate in neurons of the suprachiasmatic nucleus. J Neurosci 23: $1593-1604$.

D’Angelo E, Nieus T, Maffei A, Armano S, Rossi P, Taglietti V et al (2001). Theta-frequency bursting and resonance in cerebellar granule cells: experimental evidence and modeling of a slow $\mathrm{k}+-$ dependent mechanism. J Neurosci 21: 759-770.

Dieudonne S (1998). Submillisecond kinetics and low efficacy of parallel fibre-Golgi cell synaptic currents in the rat cerebellum. J Physiol 510(Part 3): 845-866.

Dugue GP, Brunel N, Hakim V, Schwartz E, Chat M, Levesque M et al (2009). Electrical coupling mediates tunable low-frequency oscillations and resonance in the cerebellar Golgi cell network. Neuron 61: 126-139.

Fitzpatrick LE, Jackson M, Crowe SF (2008). The relationship between alcoholic cerebellar degeneration and cognitive and emotional functioning. Neurosci Biobehav Rev 32: 466-485.

Foley TD, Rhoads DE (1994). Stimulation of synaptosomal Na+,K(+)ATPase by ethanol: possible involvement of an isozyme-specific inhibitor of $\mathrm{Na}+\mathrm{K}(+)$-ATPase. Brain Res 653: 167-172.

Forti L, Cesana E, Mapelli J, D'Angelo E (2006). Ionic mechanisms of autorhythmic firing in rat cerebellar Golgi cells. J Physiol 574: 711-729.

Foster DM, Huber MD, Klemm WR (1989). Ethanol may stimulate or inhibit $(\mathrm{Na}++\mathrm{K}+)$-ATPase, depending upon $\mathrm{Na}+$ and $\mathrm{K}+$ concentrations. Alcohol 6: 437-443.

Freund RK, van Horne CG, Harlan T, Palmer MR (1993). Electrophysiological interactions of ethanol with GABAergic mechanisms in the rat cerebellum in vivo. Alcohol Clin Exp Res 17: $321-328$

Galindo R, Zamudio P, Valenzuela C (2005). Alcohol is a potent stimulant of immature neuronal networks: implications for fetal alcohol spectrum disorder. J Neurochem 94: 1500-1511.

Genet S, Kado RT (1997). Hyperpolarizing current of the $\mathrm{Na} / \mathrm{K}$ ATPase contributes to the membrane polarization of the Purkinje cell in rat cerebellum. Pflugers Arch 434: 559-567.

Gowen E, Miall RC (2007). The cerebellum and motor dysfunction in neuropsychiatric disorders. Cerebellum 6: 268-279.

Hamada K, Matsuura H, Sanada M, Toyoda F, Omatsu-Kanbe M, Kashiwagi A et al (2003). Properties of the $\mathrm{Na}+\mathrm{K}+$ pump current in small neurons from adult rat dorsal root ganglia. $\mathrm{Br} J$ Pharmacol 138: 1517-1527.

Hanchar HJ, Dodson PD, Olsen RW, Otis TS, Wallner M (2005). Alcohol-induced motor impairment caused by increased extrasynaptic GABA(A) receptor activity. Nat Neurosci 8: 339-345.

Hines ML, Carnevale NT (2001). NEURON: a tool for neuroscientists. Neuroscientist 7: 123-135.

Hirono M, Yamada M, Obata K (2009). Ethanol enhances both action potential-dependent and action potential-independent GABAergic transmission onto cerebellar Purkinje cells. Neuropharmacology 57: 109-120.

Huang C, Huang R (1992). Intoxication and acute tolerance to ethanol: cerebellar granule neurons. In: Watson RR (ed). Alcohol and Neurobiology: Brain Development and Hormone Regulation. CRC Press: London. pp 45-68.

Huang CM, Huang RH (2007). Ethanol inhibits the sensory responses of cerebellar granule cells in anesthetized cats. Alcohol Clin Exp Res 31: 336-344.
Israel Y, Kalant H, Laufer I (1965). Effects of ethanol on $\mathrm{Na}, \mathrm{K}$, Mg-stimulated microsomal ATPase activity. Biochem Pharmacol 14: $1803-1814$.

Ito M (2006). Cerebellar circuitry as a neuronal machine. Prog Neurobiol 78: 272-303.

Kanichay RT, Silver RA (2008). Synaptic and cellular properties of the feedforward inhibitory circuit within the input layer of the cerebellar cortex. J Neurosci 28: 8955-8967.

Kim JH, Sizov I, Dobretsov M, von Gersdorff H (2007). Presynaptic $\mathrm{Ca} 2+$ buffers control the strength of a fast post-tetanic hyperpolarization mediated by the alpha3 $\mathrm{Na}(+) / \mathrm{K}(+)$-ATPase. Nat Neurosci 10: 196-205.

Ledig M, Kopp P, Mandel P (1985). Effect of ethanol on adenosine triphosphatase and enolase activities in rat brain and in cultured nerve cells. Neurochem Res 10: 1311-1324.

Maex R, De Schutter E (2005). Oscillations in the cerebellar cortex: a prediction of their frequency bands. Prog Brain Res 148: 181-188.

Mereu G, Fadda F, Gessa GL (1984). Ethanol stimulates the firing rate of nigral dopaminergic neurons in unanesthetized rats. Brain Res 292: 63-69.

Munakata M, Fujimoto M, Jin YH, Akaike N (1998). Characterization of electrogenic $\mathrm{Na} / \mathrm{K}$ pump in rat neostriatal neurons. Brain Res 800: 282-293.

Niesen CE, Baskys A, Carlen PL (1988). Reversed ethanol effects on potassium conductances in aged hippocampal dentate granule neurons. Brain Res 445: 137-141.

Offenhauser N, Castelletti D, Mapelli L, Soppo BE, Regondi MC, Rossi P et al (2006). Increased ethanol resistance and consumption in Eps8 knockout mice correlates with altered actin dynamics. Cell 127: 213-226.

Okamoto T, Harnett MT, Morikawa H (2006). Hyperpolarizationactivated cation current (Ih) is an ethanol target in midbrain dopamine neurons of mice. J Neurophysiol 95: 619-626.

Perkins KL (2006). Cell-attached voltage-clamp and current-clamp recording and stimulation techniques in brain slices. J Neurosci Methods 154: 1-18.

Pulver SR, Griffith LC (2010). Spike integration and cellular memory in a rhythmic network from $\mathrm{Na}+\mathrm{K}+$ pump current dynamics. Nat Neurosci 13: 53-59.

Rangaraj N, Kalant H (1982). Effect of chronic ethanol treatment on temperature dependence and on norepinephrine sensitization of rat brain $(\mathrm{Na}++\mathrm{K}+)$-adenosine triphosphatase. J Pharmacol Exp Ther 223: 536-539.

Richards KS, Bommert K, Szabo G, Miles R (2007). Differential expression of $\mathrm{Na}+/ \mathrm{K}+-A T P a s e$ alpha-subunits in mouse hippocampal interneurones and pyramidal cells. J Physiol 585: 491-505.

Rogers J, Madamba SG, Staunton DA, Siggins GR (1986). Ethanol increases single unit activity in the inferior olivary nucleus. Brain Res 385: 253-262.

Rossi DJ, Hamann M, Attwell D (2003). Multiple modes of GABAergic inhibition of rat cerebellar granule cells. J Physiol 548: 97-110

Schmahmann JD (2004). Disorders of the cerebellum: ataxia, dysmetria of thought, and the cerebellar cognitive affective syndrome. J Neuropsychiatry Clin Neurosci 16: 367-378.

Servais L, Hourez R, Bearzatto B, Gall D, Schiffmann SN, Cheron G (2007). Purkinje cell dysfunction and alteration of long-term synaptic plasticity in fetal alcohol syndrome. Proc Natl Acad Sci USA 104: 9858-9863.

Siggins GR, Pittman QJ, French ED (1987). Effects of ethanol on CA1 and CA3 pyramidal cells in the hippocampal slice preparation: an intracellular study. Brain Res 414: 22-34.

Solinas SM, Forti L, Cesana E, Mapelli J, De Schutter E, D’Angelo E (2007). Computational reconstruction of pacemaking and intrinsic electroresponsiveness in cerebellar Golgi cells. Front Cell Neurosci 1: 1-12. 
Soteropoulos DS, Baker SN (2006). Cortico-cerebellar coherence during a precision grip task in the monkey. J Neurophysiol 95: 1194-1206.

Sullivan EV, Harding AJ, Pentney R, Dlugos C, Martin PR, Parks $\mathrm{MH}$ et al (2003). Disruption of frontocerebellar circuitry and function in alcoholism. Alcohol Clin Exp Res 27: 301-309.

Swann AC (1983). Brain (Na+,K+)-ATPase. Opposite effects of ethanol and dimethyl sulfoxide on temperature dependence of enzyme conformation and univalent cation binding. J Biol Chem 258: $11780-11786$.

Syapin PJ, Alkana RL (1986). Ethanol-induced inhibition of mouse brain adenosine triphosphatase activities: lack of interaction with norepinephrine in vitro. Alcohol Clin Exp Res 10: 635-640.

Syapin PJ, Chen J, Alkana RL (1985). Effect of norepinephrine on inhibition of mouse brain $(\mathrm{Na}++\mathrm{K}+)$-stimulated, $(\mathrm{Mg}++)-$ dependent, and $(\mathrm{Ca}++)$-dependent ATPase activities by ethanol. Alcohol 2: 145-148.

Takeuchi A, Tatsumi S, Sarai N, Terashima K, Matsuoka S, Noma A (2006). Ionic mechanisms of cardiac cell swelling induced by blocking $\mathrm{Na} / \mathrm{K}+$ pump as revealed by experiments and simulation. J Gen Physiol 128: 495-507.

Tesche CD, Karhu JJ (2000). Anticipatory cerebellar responses during somatosensory omission in man. Hum Brain Mapp 9: 119-142.
Thompson SM, Prince DA (1986). Activation of electrogenic sodium pump in hippocampal CA1 neurons following glutamate-induced depolarization. J Neurophysiol 56: 507-522.

Vos BP, Volny-Luraghi A, De Schutter E (1999). Cerebellar Golgi cells in the rat: receptive fields and timing of responses to facial stimulation. Eur J Neurosci 11: 2621-2634.

Wang YC, Huang RC (2006). Effects of sodium pump activity on spontaneous firing in neurons of the rat suprachiasmatic nucleus. J Neurophysiol 96: 109-118.

Watanabe $\mathrm{D}$, Inokawa $\mathrm{H}$, Hashimoto $\mathrm{K}$, Suzuki N, Kano $\mathrm{M}$, Shigemoto $\mathrm{R}$ et al (1998). Ablation of cerebellar Golgi cells disrupts synaptic integration involving GABA inhibition and NMDA receptor activation in motor coordination. Cell 95: 17-27.

Watanabe D, Nakanishi S (2003). mGluR2 postsynaptically senses granule cell inputs at Golgi cell synapses. Neuron 39: 821-829.

Widmer H, Lemos JR, Treistman SN (1998). Ethanol reduces the duration of single evoked spikes by a selective inhibition of voltage-gated calcium currents in acutely dissociated supraoptic neurons of the rat. J Neuroendocrinol 10: 399-406.

Xu W, Edgley SA (2008). Climbing fibre-dependent changes in Golgi cell responses to peripheral stimulation. J Physiol 586: 4951-4959.

Yan H, Li Q, Fleming RL, Madison RD, Wilson WA, Swartzwelder HS (2009). Developmental sensitivity of hippocampal interneurons to ethanol: involvement of the hyperpolarization-activated current, Ih. J Neurophysiol 101: 67-83.

Supplementary Information accompanies the paper on the Neuropsychopharmacology website (http://www.nature.com/npp) 